\title{
APPEARANCE OF PROTECTIVE CLOTHING OVER THE CENTURIES
}

\author{
Sanja Risteski ${ }^{*}$, Vineta Srebrenkoska ${ }^{1}$ \\ "University "Goce Delčev", Štip, Faculty of Technology, \\ Professional paper \\ Republic of North Macedonia \\ UDC: 687.052(091) \\ *e-mail: sanja.risteski@ugd.edu.mk \\ doi: $10.5937 /$ tekstind2004038R
}

\begin{abstract}
In the history of the costume, protective military clothing has a special place. The origins of military clothing go deep into history. Protective clothing defined as protective "cover" clothes is used to protect the body from physical attack. In the in many of the ancient civilization is noticed similarity in the appearance of military clothing, which means that Egyptian, Assyrian, Greek and Roman soldiers are dressed and armed in a similar way. In this paper the protective military clothes over the centuries, starting from Egypt, Babylon and Assyria, Crete and Mycenae, Ancient Greece and Rome, reaching the protective clothing characteristic of the medieval period slowly approaching the contemporary look of protective clothing is being analyzed.
\end{abstract}

Keywords: Military clothing, vest, cover clothing.

\section{IZGLED ZAŠTITNE ODEĆE KROZ VEKOVE}

Apstrakt: $U$ istoriji nošnje zaštitna vojna odeća ima posebno mesto. Poreklo vojne odeće seže duboko u istoriju. Zaštitna odeća definisana kao zaštitna "pokrivna" odeća koristi se za zaštitu tela od fizičkog napada. U mnogim drevnim civilizacijama primećena je sličnost u izgledu vojne odeće, što znači da su egipatski, asirski, grčki i rimski vojnici obučeni i naoružani na sličan način. U ovom radu analizirana je zaštitna vojna odeća kroz vekove, počev od Egipta, Vavilona i Asirije, Krita i Mikene, drevne Grčke i Rima, sve do zaštitne odeće karakteristične za srednjovekovni period koji se polako približava savremenom izgledu zaštitne odeće.

Ključne reči: Vojna odeća, prsluk, pokrivna odeća.

\section{INTRODUCTION}

In the past, various nations and cultures around the world used protective clothing made from natural raw materials. Initially, protective clothing and shields were made from animal skins. In order to protect themselves, humans used mimicry to "escape" from visual detection by combining a mixture of colors in order to achieve a blurred silhouette that would be less visible to enemy forces. People do not have natural masked features, but some forms of protection of the human body date back thousands of years. Prehistoric people protected their bodies with piles of grass, which they put on their bodies in order to hide and protect themselves from aggressive animals.

The oldest data about protective clothing show that the first type of protective clothing was made of leather, and the first protective clothing was found in Europe and West Asia.

Until the industrial revolution in the 19th century, clothing was generally used to protect against the weather. The industrial revolution has seen a significant increase in the use of protective clothing against industrial hazards such as heat, fire, explosion, impact, chemicals etc. The beginning of the 21st century is a period of innovation in the science of textiles and new materials. A period of transformation of the already known functions of clothing into advanced and new textile production technologies is already taking place [1].

With the advancement of civilization, wooden shields and later metal shields were used as protection. The metal was used as a protective clothing for knights in the middle Ages. During the middle Ages 
and the Renaissance, armor was considered as the most effective protection, and at the same time it was considered as a complex "jewelry" for the human body. In the period from the 14th to the 16th century, protective clothing received a satisfactory rating based on research in which clothing met the requirements in terms of weapon protection in that period. Later, with the discovery of firearms, most traditional protective clothing no longer produced the required results. In order to achieve the required protection, it was necessary to increase the weight of the armor to about 50 $\mathrm{kg}$, which was a huge weight for the carriers [2].

Protective clothing made from leather was originally designed to be worn under armor, but later only a few layers of leather were placed on the soldiers' bodies, which in some way facilitated their movement. One of the oldest records of the use of "soft protection" speaks of medieval Japanese who used silk armor. The reason for the use of silk as protective clothing occurred from a series of examples in which the bullet lost its speed when touching the silk fabric.

The first commercial protective clothing was promoted in the $1800 \mathrm{~s}$. The protective clothing in the form of protective vests was made of silk fabric, because the silk fabric reduces the speed of penetration of the bullet. The use of 18 to 30 layers of silk has provided a higher degree of protection for the wearer's body. Towards the end of the 19th century, the smokeless gunpowder had a great influence in terms of reducing the elements of disruption in the uniform, and it became more and more adapted to the environment and gave a greater camouflage for the soldier. In this way, the path of the contemporary soldier was traced. Patterns and camouflage colors of protective clothing have been constantly improved in order to achieve better technological and design results for the protection of the human body in various environments including jungles, pastures and deserts [3]. Significant scientific experiments were conducted in the 20th century to create "perfect" protective textiles. Scientists in this period were doing significant research on the materials, comfort, effectiveness and quality of textiles that will be used to obtain protective clothing. Contemporary protective clothing was made of thin fibers that gave less weight of the clothing and a greater degree of protection. This new type of protection offers effective, lightweight and bulletproof clothing, marking the beginning of a new, modern generation of protective clothing. The discovery of artificial fibers creates a perfect base for further production of other types of artificial fibers.

New fibers that were considered as "evolutionary" were designed to provide greater comfort, flame resistance, quick drying, higher degrees of whiteness and shine. The new fibers in different shapes and thicknesses were made to meet special needs. The wide range of possibilities for designing protective clothing derived from those fibers became reality. Innovations in materials and manufacturing technologies lead to the discovery of new textile materials (from nylon, glass, Kevlar and many other synthetic fibers) that provide protective clothing with a remarkable improvement in the level of protection, with significant weight loss a powerful combination to improve efficiency and the mobility of the military forces.

Contemporary materials that began to be used in the late 20th century, and already in the 21 st century will see significant growth, especially in terms of their modernization. The discovery of artificial fibers creates a perfect base for further production of other types of artificial fibers. With the use of new generations of synthetic fibers, the greatest achievements have been made in terms of the weight of protective clothing and, of course, the level of protection. The biggest efforts today are aimed at better design in terms of appearance and functionality of protective clothing, and the goals are aimed at obtaining protective clothing with modular design, high degree of comfort and protection, as well as easy removal of protective clothing from the soldier's body. which at times is of paramount importance in saving the lives of many soldiers. The design of protective clothing, in turn, involves the proper selection of material or a combination of materials to prevent the penetration of bullets and trauma effect, as well as determining the number of layers of protective material to achieve the required protection.

The final weight is a very important factor in the design when choosing a material resistant to bullets. The goal is to design lighter protective clothing that will provide the required protection on the other hand, and still provide smooth movement $[3,4,5]$.

\section{THE PROTECTIVE MILITARY CLOTHES OF THE BABYLONIANS AND THE ASSYRIANS}

The Babylonian expansion takes place after the collapse of the Sumerian Empire in the late third millennium. Under Hammurabi, Babylon became the seat of a new Mesopotamian empire. Babylon had a regular army, which was considered as the best army in the world.

In Babylon, fabrics made of wool and linen were known, while the use of cotton was less common. The protective clothing was made of leather, which was 
later coated with metal tiles for the infantry and cavalry. In term of materials, beside wool and linen, silk imported from China was also used.

The Assyrians were well-known soldiers, and their military equipment and weapons were an example to many nations. The protective clothing consisted of tight-fitting pants, and the tunics were short and decorated with fringes, with a wide belt and conical caps set with leather. The army wore helmets, and the armor was made of metal scales. Arrows, straight swords, spears, and shields were also used. An important ornament of the governor was the white crown, which was worn only by him. The court dignitaries wore headbands that also showed a certain rank $[6,7]$. and his sons. The soldiers were grouped into divisions consisting of 5,000 soldiers. There were also smaller divisions consisting of 50 soldiers. The army consisted mainly of volunteers, and slaves were once used as soldiers to protect their own land.

Military clothing in Egypt was quite different from everyday clothing. Soldiers mostly wore white or striped shendyt (Figure 2). In the Middle Kingdom, the Scythians were fortified with a kind of apron made of leather, with a belt of cloth or colored leather. The head was protected by a stamped wig or a thicker cap, as the helmet was unknown to Egyptians.

The commanders wore armor and a helmet made of crocodile skin. They used a short sword, a

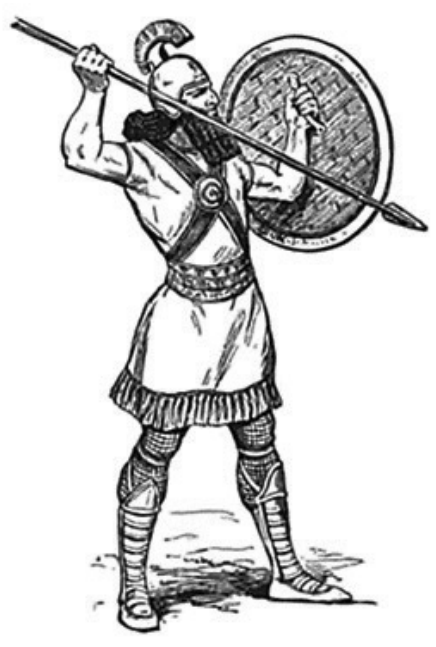

Figure 1: Assyrian soldier

\section{THE PROTECTIVE MILITARY CLOTHES IN EGYPT}

The Egyptians were a peaceful people, not volatile, but the prosperity of their citizens was in some ways challenging for their less prosperous neighbors. They have been constantly forced to develop defensive strategies against various attacks caused by their neighbors. They believed that the god protected pharaohs and soldiers from attacks and wars.

The king was an absolute ruler with unlimited power and authority that extended to the whole kingdom. Soldiers in Egypt were considered members of the upper castes, and their importance was equated with that of priests, writers, and courtiers. The army in ancient Egypt consisted of infantry and volunteer troops. During the Middle Kingdom period, the military was formed through recruits from other countries, and later most of the troops were from Egypt. These corps consisted of pharaoh's recruits and bodyguards. The Egyptian army was led by Pharaoh knife, an ax, a spear, and an arrow. The shield had a different shape, but it was never circular. The underside of the shield was always flat, and the top was rounded, sometimes narrower than the bottom. The shield was made of hippopotamus leather covered with metal parts $[8,9]$.

\section{THE PROTECTIVE MILITARY CLOTHES IN CRETE AND MYCENAE}

A special area in the history of the costume is the "Greek world", which from the very beginning has been the subject of great interest of archaeologists and historians. Characteristic of the clothes in Crete and Mycenae was that the clothes were tailored.

The color of the military uniform in Crete was blue and yellow. Soldiers wore a two-horned fur hat on their heads. They were armed with two spears. The ruler/ governor wore a crown made of peacock feathers, a necklace and a bracelet. 
The military uniform of the Mycenaean's contained completely different elements than the Cretan one. The military uniform consisted of metal helmets, with a ridge and better parts, which were made of leather and decorated with two horns, as well as fur hats that were characteristic of the Cretan soldiers. Soldiers as protection for the body wore tunics and leather protective leg covers.

\subsection{Protective military clothes in ancient Greece}

According to the preserved works of art from the $8^{\text {th }}$ and $9^{\text {th }}$ century, and confirmed by the numerous naked figures from the statues exhibited in the museums, it can be concluded that the Greeks went naked in battle, armed only with a shield, sword and body armor.

In real life, protective clothing consisted of tunics reinforced with metal plates and worn on the legs. The Greek military consisted of heavily armed Hoplite infantry, lightly armed Pilaster infantry and cavalry. The hoplites wore a red tunic on which they wore bronze or leather armor, with metal accessories that were forged or sewn, and reached to the belt, and from the belt continued with protective leather straps. The shoulders were protected with flat plates, and protective covers were worn on the legs.

The light infantry wore leggings that looked like leather boots made of leather and a double-breasted tunic or leather that was fastened with a metal strap. They wore chlamydia on their shoulders, which they passed over their left shoulder when they went to battle $[10,11]$.

\section{THE PROTECTIVE MILITARY CLOTHES IN ROME}

The Romans' military clothes changed over time, as the Romans accepted all the things that were practical and useful from the enemy. The secret of Rome's relatively rapid progress came in the form of alliances with then powerful and finally enslaved enemies who had become loyal Roman allies.

Rome successfully established colonies in the conquered territories that provided control over them. In the term of military clothing is interesting to note that

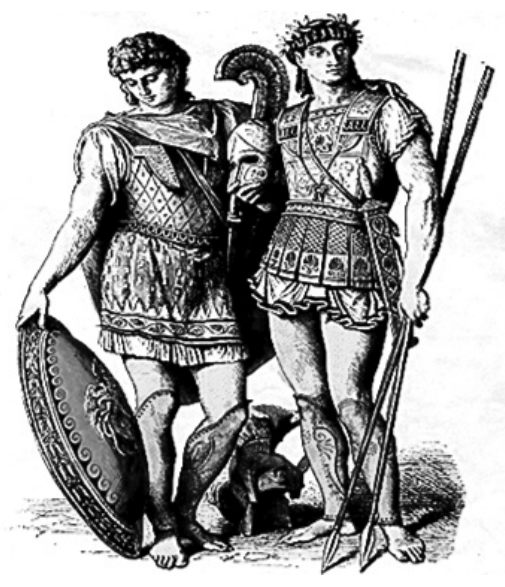

Figure 3: Greek soldiers

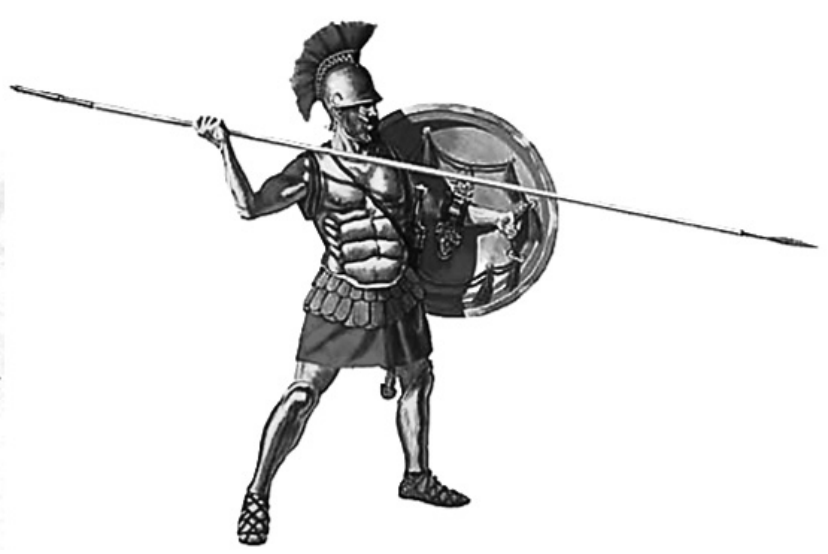

Figure 4: Appearance of Hoplite soldier
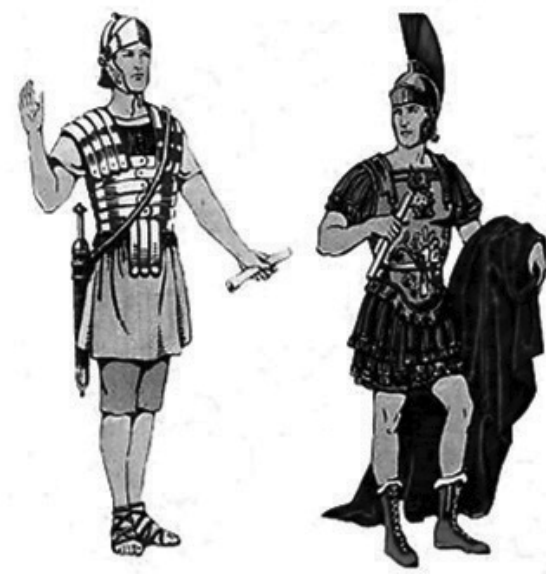

Figure 5: Roman military clothing

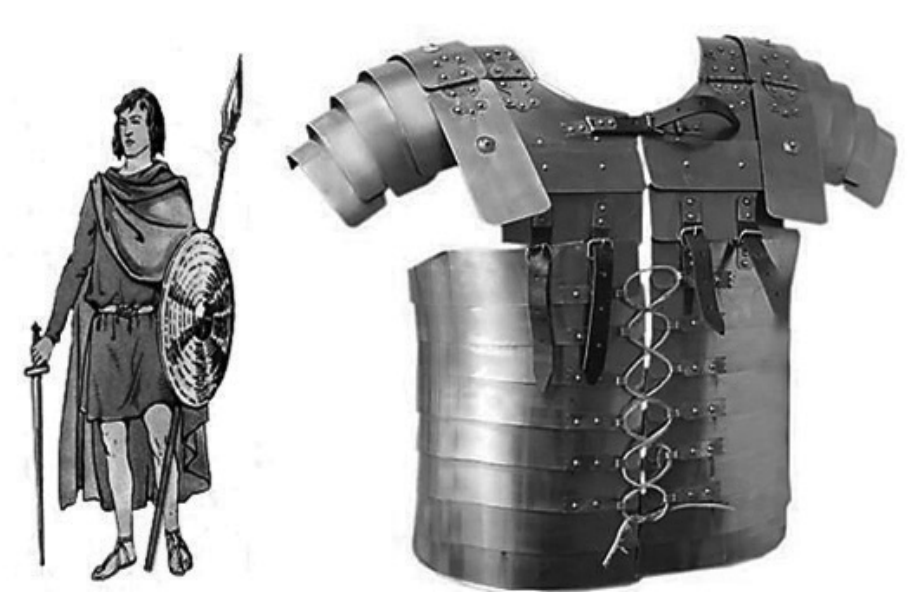

Figure 6: Appearance of a chest armor Lorica 
the pieces of clothing such as the tunic and the sagum, were subject to change with the exception of the pants that did not changed over the time.

The classic armament consisted of a chest amour called Lorica, consisting of metal belts decorated with metal plates or wires. The commanders wore metal armor that was tailored to the shape of the body and richly decorated with reliefs. A belt was worn over the armor, which was a kind of decoration, as the removal of the belt was considered as a punishment.

The Roman helmet has been also redesigned from leather to metal, and as an integral part of the helmet were protective parts for the cheeks and the neck. The cavalry had a leather armor and a leather shield $[12,13,14]$.

\section{PROTECTIVE CLOTHES IN THE MIDDLE AGES}

\subsection{Plate armour}

The Middle Ages bring the development of new modes of warfare encompassing both pitched battles and siege warfare. New weapons technology prompted new defensive technologies, for example the introduction of cross-bows led quickly to the adoption of plate amour rather than chain mail. Plate amour, which protected the chest and the lower limbs, was used by the ancient Greeks and Romans, but it fell into disuse after the collapse of the Roman Empire because of the cost and work involved in producing a Lorica or comparable plate amour. Single plates of metal amour were again used from the late 13th century. By the end of the 14th century, larger and complete full plates of amour had been developed. During the early 1500 s the helmet and neck guard design was reformed to produce the so-called Nürnberg amour, many of them masterpieces of workmanship and design.

In this period, the general trend was towards mail, scale, or lamellar armour. Full plate armour was expensive to produce and remained therefore restricted to the upper strata of society, lavishly decorated suits of armour remained the fashion with 18th century nobles and generals long after they had ceased to be militarily useful on the battlefield due to the advent of powerful muskets. Reduced plate armour also became popular among 16th century. This mass-produced armour was often heavier and made of lower quality metal than knight armour. From the 15th century on, armour specifically designed for jousting (rather than for battle) and parade armour also became popular. Many of the latter were decorated with biblical or mythological motifs.

\subsection{Torso (Brigandine 12th to 16th century)}

A brigandine, was a form of body armour, generally canvas or leather, lined with small oblong steel plates riveted to the fabric. The form of the brigandine was essentially the same as the civilian doublet, though it is commonly sleeveless. Many brigandines appear to have had larger, 'L-shaped' plates over the lungs. Attached plates to the fabric were often decorated, and often embossed with a design. The brigandine was commonly worn over a gambeson and mail shirt and it was not long before this form of protec-
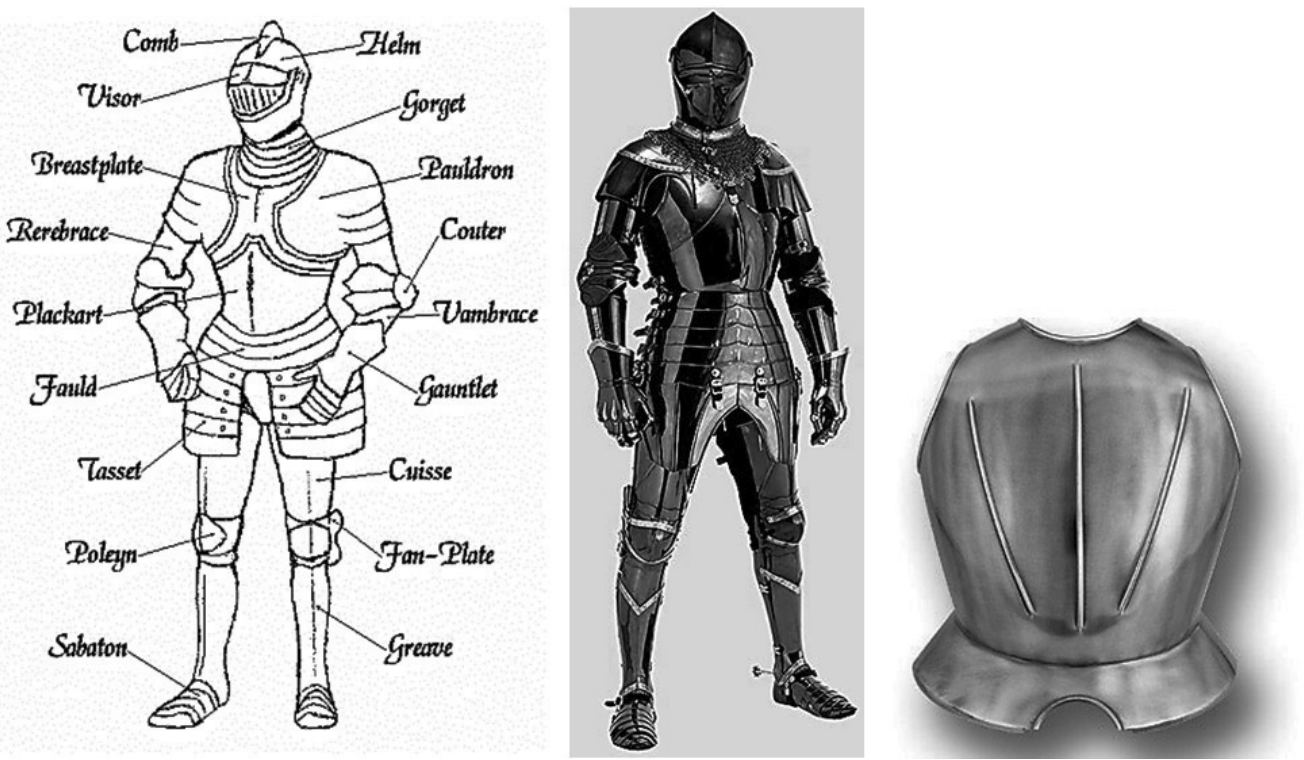

Figure 7: Appearance of a medieval military clothes

Figure 8: Appearance of a Cuirass 
tion was commonly used by soldiers ranging in rank from archers to knights. Even with the gambeson and the mail shirt, a wearer was not as protected as when wearing plate, which was typically more expensive. Cuirass (Figure 8) (The French term means «one with a cuirass", the breastplate armour which they wore) was a piece of armour formed of a single, or multiple pieces of metal or other rigid material, which covers the front of the wearer's torso. This kind of protection was used and popular in 14th century. In a suit of armour this piece was generally connected to a back piece and cuirass cold refer to the complete torso protecting amour [15].

\section{THE PROTECTIVE MILITARY CLOTHES IN THE EASTERN ROMAN EMPIRE - BYZANTIUM}

Byzantine clothing is a modified Roman dress, enriched with colors and status features. Byzantine clothing is dominated by hierarchical symbols, such as color, ornaments, and other statues, so it is often referred to as clothing in which everything is precisely defined, set in hard and straight lines. A Byzantine infantryman wore metal body armor and helmet. Iron mail or bronze scale was the most common body armor. But not everyone purchased such uniforms, some spent their allowance on a large shield, since it could offer sufficient protection. Soldiers were free to use armor handed down by family members, buy armor from soldiers who had completed their service or wear discontinued styles of armor if they preferred it to (or could not afford) the latest issue. The basic dress was a loose-fitting long-sleeved tunic. Most tunics must have been made of undyed wool, linen or a mix of wool and linen. Soldiers that were wealthier purchased red dyed tunic as red was considered a military color. Less common colors were blue, yellow and green. As for legwear, it depended on the environment. In cold climate, long trousers or breeches were being worn. Knee high socks bound up with laces were also used. In warmer climate, soldiers wore lower leg coverings without trousers or breeches. To keep out wet and cold, soldiers had a thick wool cloak. In the 12th to 15th centuries there was Turkish influence as well as input from the increasingly powerful Western European nations.

\section{PROTECTIVE MILITARY CLOTHES DURING THE RENAISSANCE}

Significant protective clothing documentation dates back to the 15th century. The modern concept of the individual artist begins to emerge at the end of the fourteenth century. In Renaissance Europe, northern Italy and southern Germany were the largest centers for the production of shielding armor and exporters of their products throughout Europe. The center for the production of shielded armor in the 15th century was the Italian city of Milan, home to the earliest relatively well-documented protective armor. In medieval Italy, the luxury of military dress was developed. The splendor of (battle) dress in the 15th century is also at its peak in France. The French military was known for its white crosiers worn over protective clothing, unlike the English for wearing black, and in some documents mention that they were in red color. During the 16th century, Filippo Negroli (1510-1579) was considered one of the most deserving and wellknown manufacturers of protective clothing (armor). In 1538, Francesco Maria Della Rovera authorized Filippo Negroli to design a bulletproof vest. In 1561, Maximilian II took part in testing his bulletproof vest, although the protection effect offered by the protective vest was debatable at that time. The etymological meaning of the word "bullet" to which the word "protection" would be added in 1500 would mean that the term "impenetrable" would refer to clothing that prevents the penetration of bullets. The most famous workshops for making protective clothing (armor) were the cities that specialized in certain types of production. Nuremberg has long had a high reputation for making protective clothing (armor) in the 16th century. Although England, France and the Netherlands import most of their weapons and armor from Italy and Germany, there is evidence that these countries still have prosperous centers of national production. In France, the most important centers for making protective military clothes were Paris, Lyon, Bovo and Chartres. There is little information about the production of weapons and protective armor in the Netherlands and Spain, although it is known that Burgos and Seville were considered the leading centers for the production of protective armor $[16,17]$.

\section{PROTECTIVE MILITARY CLOTHES IN EUROPE IN THE 17TH CENTURY}

The seventeenth century is a period of great discoveries that traced the road for the creation of the modern world. It is the century of the founders of modern science, the century of Galileo Galilei and Isaac Newton, of Rene Descartes, the founder of modern philosophy, of Thomas Hobbes and John Locke, the founders of modern political theory. To gain an advantage in wars against other states, European governments have invested in research aimed at more modern military technology. The 17th century is con- 
sidered a period of military revolution, which allowed Europe to defeat most non-European nations. During this period there is a certain division of arm in the military. The armament is the same, but we cannot still talk about the uniformity of the army. From 1600 to 1650 , the military uniform consisted of a coat, wide knee-length trousers, socks, shoes or boots, a collar and a hat. The armor was characteristic of infantry, spearmen, and armor. The generals wore thin metal armor as a representative ornament. They also wore a helmet with armor. The closed helmet went out of use in the 1940s and since then has been worn with a Hungarian hat. In the second half of the 17th century, all types of weapons, both cavalry and infantry, wore only armor and helmets. The military has retained full upper armor as a symbol of Knight's dignity until the first half of the 18th century. The soldier uniform by his pattern is similar to the civilian one, as the leather coat and boots were worn in other social instances as well.

\section{PROTECTIVE MILITARY CLOTHES IN THE 18th AND 19th CENTURIES}

The eighteenth century is considered a period in which special emphasis is given to the French costume that dominates throughout Europe. In the clothes of the $18^{\text {th }}$ century, there are specifics that indicate the arrival of new ideas and understandings. It is a period of great social change that will lead to a change in class relations over the past centuries. In the early $18^{\text {th }}$ century, the uniform was introduced in all European armies. It had a civilian cut, but it was quite decorated, as a recognizable element that made it different from civilian clothes. The military coat was open until 1730, with longer sleeves and short cuffs, combined with tight pants, a collar and a hat, and after 1750 the uniform became very tight. During this period, the coat also received bangles that were used to hold the belt. During this period, the helmet appeared, which is
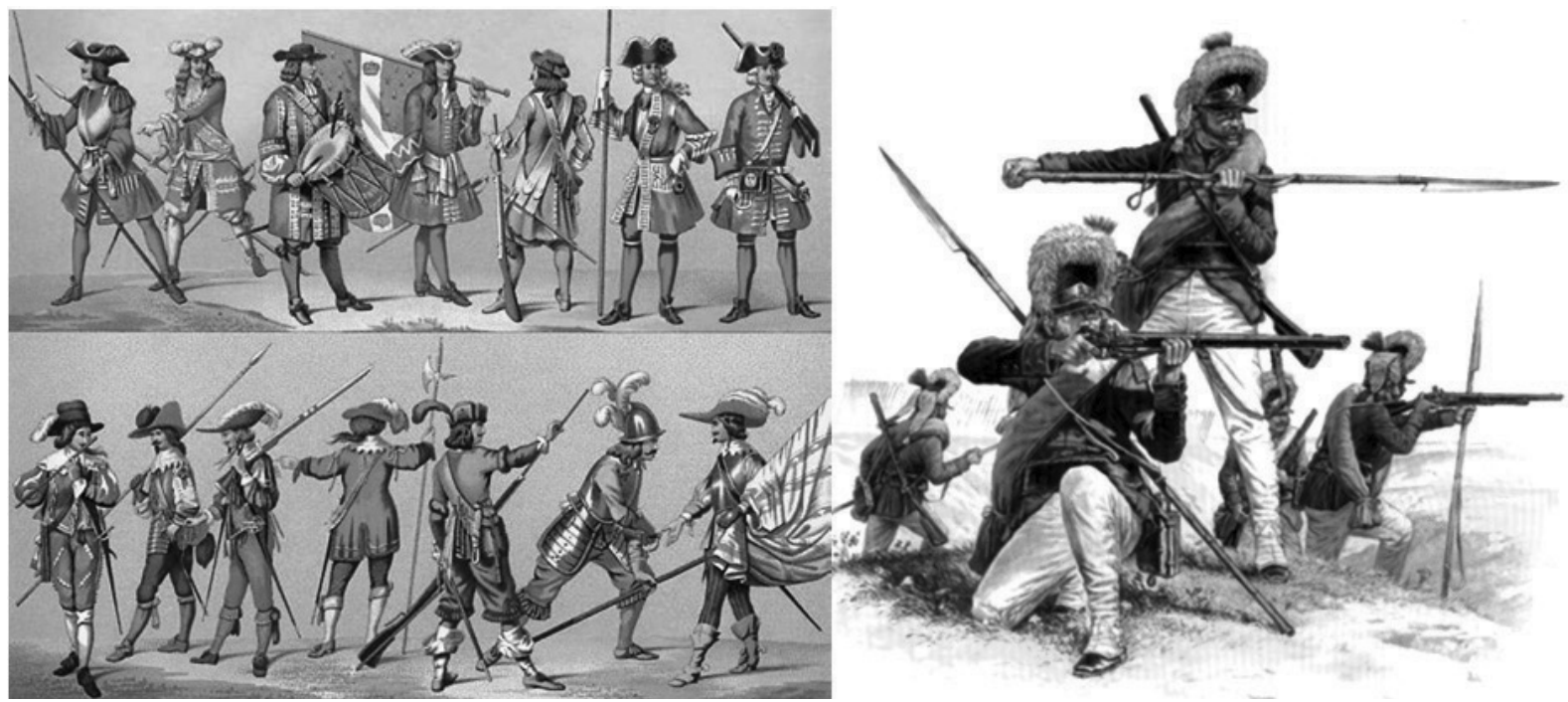

Figure 10: Military uniforms in the $17^{\text {th }}, 18^{\text {th }}$ and $19^{\text {th }}$ centuries

In France, Louis 14 was the first who introduced uniforms to his army in 1672. The military uniform was quite similar to the civilian one, and consisted of a long coat, which was fastened along the entire length, a hat, and tight trousers with length up to the knees, shoes and a round sleeveless gown. The cavalry wore boots. The shoes were black and the socks were worn over trousers. They wore a hat on their heads. The original colors of the military uniform were neutral: gray-yellow with cuffs in bright colors. The Royal Guard wore brightly colored uniforms: the French guard wore blue, the gendarmes and musketeers wore red, and the Scottish guard wore white uniforms. The artillery was dressed in blue uniforms [18, 19]. believed to have originated from the Roman helmets with a feather. From the first half of the 19th century, the cavalry wore cavalry trousers, which were fastened along their entire length. Wide riding pants appear in France, which were covered with leather on the inside.

\section{1. The first commercial protective vest}

Casimir Zeglen has promoted the production of the first commercial protective vest to become known to the public in the late 1800s. The protective vests were made of silk fabric examined by Dr. George Goodfellow of Arizona. In his research, he found that silk fabric slowed down the penetration rate of the bullet. In 1881, in a fire fight in Arizona, Goodfellow noticed that a serious injury had been avoided, thanks 
to a silk handkerchief that protected the injured man. Based on the findings of Goodfellow and several other similar incidents, Zeglen produced an armored protective vest made of silk in the late 19th century. Undoubtedly, protective vests were very expensive. In the late 1920s and 1930s, bandits in the United States began wearing less expensive protective vests made of multiple layers of cotton fabric. During World War II, a large number of protective vests were designed for the U.S. Army, but most of them were very heavy [20].

\section{MILITARY CLOTHES IN THE 20TH CENTURY}

The experiences of the English from the colonial wars speak of the use of less conspicuous military clothes. The beginnings of such understandings represent the uniform of hunters in all countries during the Napoleonic Wars. They wore green uniforms with black belts, less noticeable than the clear colors of infantry uniforms and their white belts. These experiences have yielded significant results in England in the 1970s, when a blouse with outer pockets, trousers and a tropical helmet were designed. Already during this period, all countries are introducing uniforms in dark green, dark blue and navy-blue colors, which protects soldiers by equalizing them with the environment, and making them less visible to the enemy. In World War I, all countries used such uniforms, with the exception of France, which introduced this type of uniform in 1915.

World War II brought significant changes to the uniforms meaning and their functionality. The uniform becomes practical and functional by placing pockets on blouses/vests and trousers that become wide and are worn with high boots. Innovation is the "Leopard" uniform - with colorful spots, which equates soldiers with the environment. This clothing was primarily intended for the special army, due to the better camouflage it offers.

During World War II, the soldiers' blouses were wrapped around their necks, exposing their shirts and ties, which became a necessary prop in the uniform of ordinary soldiers. The steel helmet was an integral part of the military uniform not only in wars but also in parades. Based on the experiences from the previous war, the possibilities for obtaining a new uniform with a chameleon color were examined, which would be even better adapted to the environment. The problem with the appearance of uniforms has always been one of those areas where constant research is being done to improve their appearance and function. One thing is for sure - while in previous centuries there were distinctive uniforms with strong colors and markings, in the late 19th century the smokeless gunpowder made a great impact in terms of reducing the elements of conspicuous in the uniforms and it is increasingly adapting to the environment and giving higher camouflage for the soldier. In this way, the path of the contemporary soldier was traced. In 1920, the French military conducted extensive research on protective clothing that would be worn by other armed forces. However, there was a problem because the soldiers were dressed in the same uniform, so there was no way to make a distinction between soldiers and the enemy. It is for these reasons that US troops avoid wearing this type of uniform, but still protective camouflage clothing was worn in military operations during the 1950s and during the Vietnam War, the Gulf War and other military operations. Patterns and colors of protective clothing have been constantly refined in order to achieve better technological and design results to protect the human body in a variety of environments including jungles, pastures and deserts.

The next generation of protective clothing started during World War II. The protective clothing was in the form of a protective vest made of nylon fibers that was not effective against most pistol/revolver ammunition. The vest was very difficult to carry and it was intended only for the military. Advanced protective clothing appeared in the 1960s. The protective clothing was made of thin fibers that gave the clothing less weight and higher level of protection. This new type of protection offers effective, lightweight and bulletproof clothing, marking the beginning of a new, modern generation of protective clothing. In 1960, protective clothing was worn by civilians as an ironic response to the Vietnam War. The trend was short-timed but reappeared in the 1980s. In the 1990s, several designs of protective clothing or civilian use were made, men's sports jackets, and women's skirts and dresses [21].

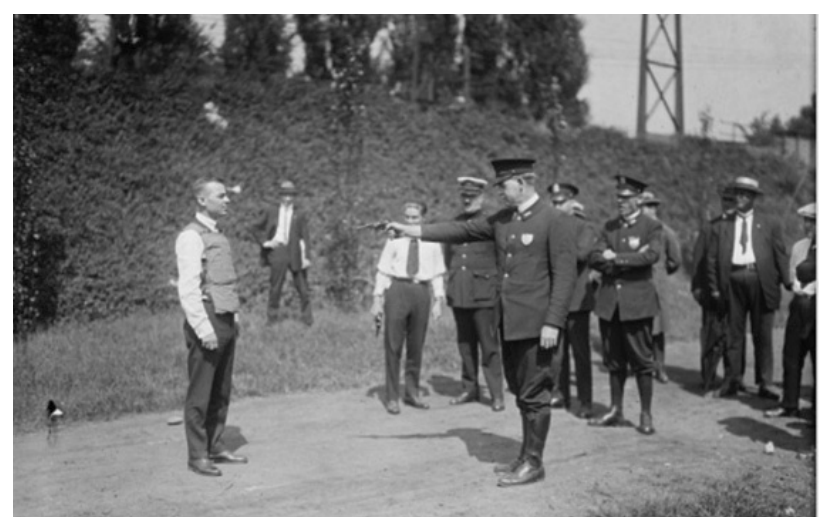

Figure 11: Demonstrating a bullet-proof vest in the year 1923. (Photo: Library of Congress/LC-DIGhec-43388) 


\section{CONTEMPORARY PROTECTIVE CLOTHING DESIGN}

New materials used for bulletproof vests design are artificial materials. Their weight and comfort properties have improved significantly over the last few decades. The protective vest in the 21 st century, offers a high degree of protection for soldiers. Protective clothing is made of synthetic materials whose properties meet the requirements for protective clothing. The modern protective vest has a modular design, which means that only the basic part of the vest can be worn, or if necessary, accessories or additional protection can be attached to the basic part.

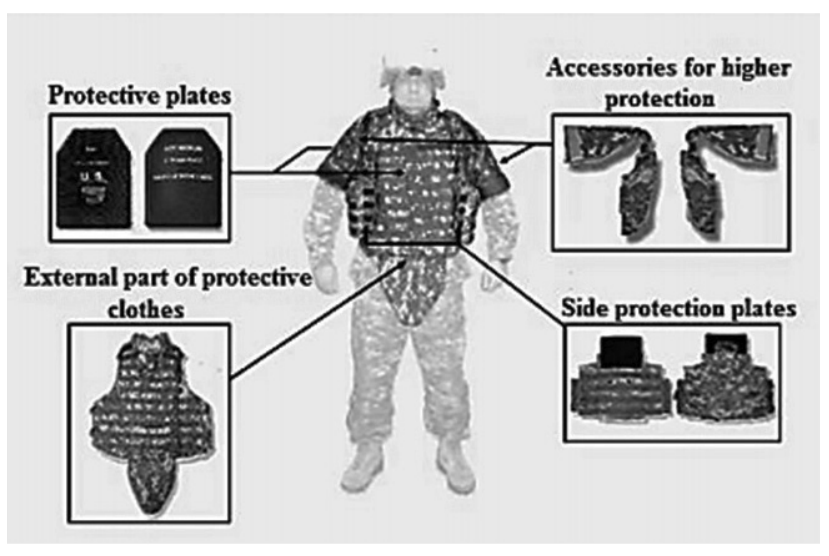

Figure 12: Appearance and integral parts of advanced protective vest

In the contemporary protective vest, there are openings for inserting ballistic material that protects the body from bullet penetration. The construction shape of the protective vest allows flexibility and smoothness in the movements of the soldier. The high degree of protection offered by contemporary protective clothing is the result of the numerous accessories and removable parts that are placed on the protective vest as needed. There are different types of removable parts that are mounted on the vest as needed: shoulder protection, neck protection - which is also equipped with ballistic material, in order to provide the protection from knife stings, or other sharp objects, protection of the abdomen, protection of the lateral parts of the body. The color of the protective clothing varies depending on the environment for which it is intended - from monochromatic to camouflage.

Protective clothing, which is a trend in the 21st century, is characterized by low weight $(5-6 \mathrm{~kg})$. But if all the modular parts and necessary equipment (chemical, nuclear equipment, weather equipment, technology, special antennas that are attached to the belt, etc.) are attached to this garment, which can be worn in high-risk situations, the weight of the garment can reach and up to $48 \mathrm{~kg}$. For these reasons, it is insisted on reducing the weight of protective clothing (military vests), which would improve the mobility of soldiers, which is extremely important, especially for those involved in high-risk situations. This means that research and efforts are constantly being made to further reduce the weight and functionality of the protective clothes. Today, the advanced look of the soldier is absolutely necessary. The design that is deeply embedded in all spheres of life is very easy to weave and present in the look of protective clothing. The right choice of contemporary design with the right choice of materials will improve the mobility of soldiers and will also increase their comfort and convenience [22].

\section{CONCLUSION}

The oldest data about protective clothing show that the first type of protective clothing was made of leather, and the first protective clothing was found in Europe and West Asia.

Until the industrial revolution in the 19th century, clothing was generally used to protect against the weather. The industrial revolution has seen a significant increase in the use of protective clothing against industrial hazards such as heat, fire, explosion, impact, chemicals etc. The beginning of the 21st century is a period of innovation in the science of textiles and new materials. A period of transformation of the already known functions of clothing into advanced and new textile production technologies is already taking place.

In Babylon, fabrics made of wool and linen were known, while the use of cotton was less common. The protective clothing was made of leather, which was later coated with metal tiles for the infantry and cavalry. In term of materials, beside wool and linen, silk imported from China was also used. Military clothing in Egypt was quite different from everyday clothing. Soldiers mostly wore white or striped shendyt.

In Crete the color of the military uniform was blue and yellow. Soldiers wore a two-horned fur hat on their heads. They were armed with two spears. The ruler/governor wore a crown made of peacock feathers, a necklace and a bracelet. The military uniform of the Mycenaean's contained completely different elements than the Cretan one. The military uniform consisted of metal helmets, with a ridge and better parts, which were made of leather and decorated with two horns, as well as fur hats that were characteristic of the Cretan soldiers. 
Greeks went naked in battle, armed only with a shield, sword and body armor. In real life, protective clothing consisted of tunics reinforced with metal plates and worn on the legs. The hoplites wore a red tunic on which they wore bronze or leather armor, with metal accessories that were forged or sewn, and reached to the belt, and from the belt continued with protective leather straps. The shoulders were protected with flat plates, and protective covers were worn on the legs.

In the Roman Empire the classic armament was consisted of a chest amour called Lorica, consisting of metal belts decorated with metal plates or wires.

The Middle Ages bring the development of new modes of warfare encompassing both pitched battles and siege warfare. New weapons technology prompted new defensive technologies, for example the introduction of cross-bows led quickly to the adoption of plate amour rather than chain mail. In this period, the general trend was towards mail, scale, or lamellar amour.

In Renaissance Europe, northern Italy and southern Germany were the largest centers for the production of shielding armor and exporters of their products throughout Europe. The center for the production of shielded armor in the 15th century was the Italian city of Milan, home to the earliest relatively well-documented protective armor. In medieval Italy, the luxury of military dress was developed.

During the 16th century, Filippo Negroli (15101579) was considered one of the most deserving and well-known manufacturers of protective clothing (armor).

The seventeenth century is a period of great discoveries that traced the road for the creation of the modern world. The 17th century is considered a period of military revolution, which allowed Europe to defeat most non-European nations. During this period there is a certain division of arm in the military. In France, Louis 14 was the first who introduced uniforms to his army in 1672 .

In the military clothes of the 18th century, there are specifics that indicate the arrival of new ideas and understandings. It is a period of great social change that will lead to a change in class relations over the past centuries. Casimir Zeglen has promoted the production of the first commercial protective vest to become known to the public in the late 1800s. World War II brought significant changes to the uniforms meaning and their functionality. The uniform becomes practical and functional by placing pockets on blouses/vests and trousers that become wide and are worn with high boots. Innovation is the "Leopard" uniform - with colorful spots, which equates soldiers with the environment. This clothing was primarily intended for the special army, due to the better camouflage it offers.

The next generation of protective clothing started during World War II. The protective clothing was in the form of a protective vest made of nylon fibers that was not effective against most pistol / revolver ammunition. New materials used for bulletproof vests design are artificial materials. The high degree of protection offered by contemporary protective clothing is the result of the numerous accessories and removable parts that are placed on the protective vest as needed.

Protective clothing, which is a trend in the 21st century, is characterized by low weight $(5-6 \mathrm{~kg})$. Research and efforts are constantly being made to further reduce the weight and functionality of the protective clothes. Today, the advanced look of the soldier is absolutely necessary. The design that is deeply embedded in all spheres of life is very easy to weave and present in the look of protective clothing. The right choice of contemporary design with the right choice of materials will improve the mobility of soldiers, increase comfort and convenience.

\section{REFERENCES}

[1] Steelescribner, V. (2005). Library of daily lifeEncyclopedia of clothing and fashion Thomson Gale. a part of the Thomson Corporation.

[2] Nardo, D. (2003). The middle ages History of Weapons and Warfare. Lucent Books/Thomson Gale.

[3] Maj, C., Beyer, M., Enos, W., Col, M., \& Holmes, R. (2009). Personnel Protective Armor.

[4] Kumar, S. (1991). Advances in high performance fibers. Indian Journal of Fibre \& Textile research, 16, 52-64.

[5] Hongu, T., \& Phillips, G. (1997). New Fibers second edition. Woodhead Pblishing Ltd.

[6] Комиссаржевский, Ф. (2005). История костюма. Уникальньте материальг по истории костюма с древнейших времен.

[7] Peacock, J. (1991). The Chronicle osf Western Costume.(From the Ancient World to the late Twntieth Century). London.

[8] Brown, S. (1998). Ancient Egypt. R.I.C. Publications.

[9] Malam, J. (2006). Exploring ancient Egypt. Evans Brothers Limited, London. 
[10] Lendon, J.E. (2005). Soldiers and Ghosts: A History of Battle in Classical Antiquity. Yale University.

[11] Sage, M.M. (1996). Warfare in ancient Greece: a sourcebook. Published by Routledge London.

[12] Hope, T. (1962). Costume of the Greeks and Romans. Dover Publications.

[13] Peacock, J. (1991). The Chronicle of Western Costume, London.

[14] Dillon, M., Garland, L. (2005). Ancient Rome: from the early Republic to the assassination of Julius Caesar. Routlege New York.

[15] Istoriski pregled nosnje. интерна скрипта, Белград.

[16] Комиссаржевский, Ф. (2016). История костюма. Уникальньле материальг по истории костюма с древнейших времен. ОлмаМедиаГрупп.
[17] Bartusis, M.C. (1992). The late Byzantine army: arms and society 1204-1453. University Pensylvania press.

[18] Munck, T. (1989). Seventeenth century Europe, 1598 - 1700. Published by Palgrave.

[19] North, R. (1970). Military uniforms 1686 - 1918. Grossser \& Dunlop.

[20] Bulletproof vest - History: Encyclopedia II Bulletproof vest - History.

[21] Black, J. (2003). World War Two: a military history. Routledge.

[22] Geršak, J., Marčič, M. (2013). The complex design concept for functional protective clothing. Journal of Textile \& Clothing Technology, 62 (1-2), 38-44.

Rad primljen: 09.07.2020.

Rad prihvaćen: 02.09.2020. 